\title{
SUAMI DIPENJARA SEBAGAI ALASAN CERAI GUGAT; PERSPEKTIF FIKIH DAN LEGISLASI NEGERI MUSLIM
}

\author{
Ali Trigiyatno \\ Fakultas Syariah IAIN Pekalongan \\ Jalan Kusuma Bangsa No.09 Pekalongan jawa Tengah \\ Email: ali.trigiyatno@iainpekalongan.ac.id
}

\begin{abstract}
This paper aims to compare the provisions of fiqh with the legislation in terms of the husband being imprisoned as the reason for the wife to file for divorce in four Muslim countries. They are Indonesia as a representative of the country with the majority of the population following the Shafi'i school, Morocco representing the Maliki school, Jordan representing the Hanafi school, and Qatar representing the Hanbali school. Using a normative approach and a comparative method, this paper aims to look for aspects of similarities as well as differences from fiqh provisions compared to legislation in the four countries. The results shows that the legislation in the four countries basically takes the opinion of the Maliki and Hanbali schools which allow divorce because the husband is imprisoned. From the four countries, Indonesia has set the longest prison term, which is five years, while Morocco and Jordan are imprisoned for a minimum of three years and Qatar is two years. Indonesia and Jordan seem quite far from leaving the rules in the dominant fiqh school in their country by not following the school's fatwa adopted to prohibit divorce because the husband is imprisoned. Meanwhile, Morocco and Qatar are in accordance with the dominant schools of jurisprudence in their countries, with a few additions to more detailed and operational rules.
\end{abstract}

Key words: Imprisoned husband, Fiqh, Legislation.

\begin{abstract}
Abstrak
Tulisan ini bertujuan membandingkan ketentuan fikih dengan Undang-undang dalam hal suami dipenjara sebagai alasan istri menggugat cerai di empat negara muslim. Mereka adalah Indonesia sebagai representasi negara dengan mayoritas penduduknya menganut mazhab Syafi'i, Maroko mewakili mazhab Maliki, Yordania mewakili mazhab Hanafi, dan Qatar mewakili mazhab Hanbali. Dengan pendekatan normatif dan metode perbandingan, penulis hendak mencari segisegi persamaan sekaligus perbedaan dari ketentuan fikih dibanding legislasi di empat negara tersebut. Hasilnya adalah legislasi empat negara pada dasarnya mengambil pendapat mazhab Maliki dan Hanbali yang membolehkan cerai gugat karena suami dipenjara. Dari empat negara, Indonesia menetapkan masa penjara terlama yakni lima tahun, sedang Maroko dan Yordania dengan batasan minimal dipenjara selama tiga tahun dan Qatar dua tahun. Indonesia dan Yordania terlihat cukup jauh meninggalkan aturan dalam mazhab fikih yang dominan di negaranya dengan tidak mengikuti fatwa mazhab yang dianut untuk melarang cerai gugat karena suami dipenjara. Sementara Maroko dan Qatar masih selaras dengan mazhab fikih dengan sedikit penambahan aturan yang lebih rinci dan operasional.
\end{abstract}

Kata Kunci: Suami dipenjara, Fikih, Legislasi. 


\section{Latar Belakang}

Salah satu prinsip perkawinan Islam adalah bahwa ikatan perkawinan tidak boleh menyebabkan penderitaan pada pasangan tersebut, atau membuatnya melanggar batasbatas yang ditentukan oleh Allah. Dalam satu kaidah fikih disebutkan, adh-dhararu yuzalu yang berarti semua mudarat harus dihilangkan. Maka dari sini ditarik sebuah teori bahwa dalam perkawinan jika ada perkara atau keadaan yang membuat salah satu pasangan atau bahkan dua-duanya menderita bahaya dan kerugian maka penyebab itu harus dihilangkan, jika tidak bisa maka salah satu dapat mengajukan pemutusan pernikahan. ${ }^{1}$

Perceraian atas dasar putusan pengadilan, dalam fikih sering disebut fasakh atau pembatalan. ${ }^{2}$ Alasan atau alasan-alasan sebuah perkawinan bisa difasakh oleh pengadilan misalnya karena suami atau istri menderita cacat, suami tidak mau atau mampu menafkahi istrinya, suami atau istri murtad, suami hilang, suami pergi lama, serta suami dipenjara. ${ }^{3}$

Salah satu alasan gugat cerai yang dibuka oleh sebagian mazhab fikih dan legislasi adalah suami dipenjara atau at-tafriq $l i$ al-habs. Perceraian karena suami dipenjara, pada dasarnya adalah pengembangan dari konsep at-tafriq li adh-dharar atau perceraian karena ada bahaya atau kerugian. Suami dipenjara apalagi sampai tahunan jelas bisa mendatangkan bahaya atau kerugian bagi si istri, maka dari itu sebagian mazhab fikih membolehkan cerai gugat karena suami dipenjara sebagaimana dinyatakan dalam mazhab Maliki dan Hanbali. Memang, suami dipenjara sebagai alasan cerai gugat ${ }^{4}$ belum disepakati kebolehannya di kalangan ulama yang pada gilirannya juga disikapi berbeda dalam berbagai perundang-undangan negaranegara muslim.

Terkait penelitian terdahulu dengan tema berdekatan, ada tesis yang ditulis Mahmud Abbas Shalih Abu Isa berjudul at-Tafriq Ba ina az-Zaujaini bi Sababi Habs az-Zauj fi al-Fiqh al-Islami wa al-Ma'mul bihi $f i$ al-Mahakim asy-Syar'iyyah fi adh-Dhaffah al-Gharbiyyah. Sebagaimana terbaca dalam judulnya, tesis ini membahas perceraian karena suami dipenjara dalam fikih dan

1 Fitra Mulyawan, "Pelaksanaan Penyelesaian Perkara Cerai Gugat dengan Alasan Suami Di Penjara", Ranah Research: Journal of Multidicsiplinary Research and Development, Volume 1, Issue 4, (Agustus 2019) : 851.

2 Mahmud, Mek Wok, and Siti Zulaikha binti Mokhtar. "Mafqūd and Fasakh in the Writings of Muslim Jurists and Provisions of Malaysian Federal Territory Islamic Family Law: The Case of MH 370 Missing Plane." Intellectual Discourse 25, no. Special Is (2017): 581.

3 Iis Linawati, Dian Septiandani, Efi Yulistyowati, “Fasakh Perkawinan Karena Istri Mengalami Gangguan Jiwa: Studi Kasus Putusan Pengadilan Agama Pati No. 1899/Pdt.G/2013/PA.Pt.”, HUMANI (Hukum dan Masyarakat Madani), Volume 7 No. 3 (Desember 2017) : 188.

4 Dalam hukum positif di Indonesia, terdapat pembedaan istilah talak yang diinisiasi suami dan istri. Pasal 114 KHI menyebutkan adanya dua istilah cerai, yaitu cerai talak dan cerai gugat.

a. Cerai talak adalah putusnya hubungan perkawinan dari pihak suami. Hal ini secara tersirat termaktub dalam pasal 66 ayat (1) UU No. 1 Tahun 1974 jo. Pasal 117 KHI.

b. Cerai gugat adalah putusnya hubungan perkawinan atas gugatan cerai dari pihak istri. Secara tersirat tercantum dalam pasal 37 Ayat (1) UU No. 7 Tahun 1989 jo. Pasal 132 Ayat (1) KHI. Periksa Sulthonudin, Jefri, and Abdul Halim Musthofa. "Cerai Gugat Istri Akibat Suami Dipidana Penjara Menurut Perspektif Hukum Islam dan Hukum Positif." Legitima: Jurnal Hukum Keluarga Islam 2, no. 1 (2019): 7. 
penerapannya di Pengadilan Tepi Barat Palestina. Perbedaan dengan tulisan ini adalah negara yang diangkat jelas berbeda, karena tesis di atas membahas Palestina sementara tulisan ini empat negara dan tidak ada satupun yang membahas negara Palestina.

Masih dalam tingkatan tesis, Adnan Ali an-Najjar menulis tesis dengan judul at-Tafriq al-Qadha $i$ baina az-Zaujain Dirasah Fiqhiyyah Muqaranah bi Qanun al-Ahwal asy-Syakhshiyyah al-Falestin. Tesis yang diajukan kepada Fakultas Syariah Universitas Islamiyyah Ghaza di tahun 2004 ini berbicara perceraian berdasar putusan pengadilan secara umum, tidak spesifik karena suami dipenjara dan negara yang dibahas hanyalah Palestina. ${ }^{5}$

Berikutnya artikel yang ditulis Haidar Husain Kadzim asy-Syamri dan kawan-kawan berjudul Haqq az-Zaujah fi Thalab at-Tafriq min Zaujiha al-Mahbus Dirasah Muqaranah bi al-Fiqh al-Islami. ${ }^{6}$ Tulisan ini membahas cerai gugat karena suami dipenjara dengan perbandingan antara fikih dan legislasi di Irak. Sedang dalam tulisan ini, negara Irak tidak masuk dalam pembahasan.

Pembahasan dengan topik cerai gugat karena suami dipenjara juga dilakukan oleh Raziqi Murad Hasani lewat tesisnya yang berjudul at-Tafriq al-Qadha $i$ bi Sabab
Habs az-Zauj fi at-Tasyri' al-Jazairi wa Ba'dhi at-Tasyri'at al- 'Arabiyyah. Tulisan ini memuat pandangan fikih dan perbandinganya dengan legislasi di Aljazair. Penulis tesis ini juga menyinggung sekilas sembilan negara Arab lainnya. Memang ada dua negara yang sama dengan tulisan ini sedikit disinggung yakni Maroko dan Yordania. Namun ternyata penulis tesis ini masih menggunakan UU lama, sedang dalam tulisan ini sudah merujuk pada UU terbaru. ${ }^{7}$

Membahas topik cerai gugat juga dilakukan Salman Nashr yang dengan judul at-Tafriq al-Qadha ${ }^{i}$ baina az-Zaujain bi Sabab al-Fuqdan, wa al-Ghiyab wa al-Habs Dirasah fi al-Figh al-Islami wa Qanun al-Usrah al-Jazairi. Penulisnya membahas cerai gugat dengan alasan suami ghaib, hilang dan dipenjara di negara Aljazair. Tentunya berbeda dengan tulisan penulis yang hanya membahas cerai gugat karena suami dipenjara yang membahas empat negara di mana di dalamnya tidak termausk Aljazair. ${ }^{8}$

Dengan demikian, kajian perbandingan hukum antara fikih dan empat negara dengan latar belakang mazhab fikih yang empat sepanjang pengetahuan penulis belum ada dilakukan oleh peneliti terdahulu. Memang, perceraian dengan alasan suami dipenjara

5 Adnan Ali an-Najjar, "at-Tafriq al-Qadha`i baina az-Zaujain Dirasah Fiqhiyyah Muqaranah baina bi Qanun al-Ahwal asy-Syakhshiyyah al-Falestin”, Tesis, (Ghaza : Fakultas Syariah Universitas Islamiyyah, 2004)

6 Haidar Husain Kadzim asy-Syamri dkk., "Haqq az-Zaujah fi Thalab at-Tafriq min Zaujiha al-Mahbus Dirasah Muqaranah bi al-Fiqh al-Islami”, Journal of Kufa legal and political science 1, No. 42/2, (2019)."

7 Raziqi Murad Hasani, “ at-Tafriq al-Qadha'i bi Sabab Habs az-Zauj fi at-Tasyri’ al-Jazairi wa Ba'dhi atTasyri'at al-'Arabiyyah”, Tesis, (Julfah: Jamia'ah Ziyan 'Asyur, 2016).

8 Salman Nashr, “ at-Tafriq al-Qadha `i baina az-Zaujain bi Sabab al-Fuqdan, wa al-Ghiyab wa al-Habs Dirasah fi al-Fiqh al-Islami wa Qanun al-Usrah al-Jazairi”, al-Mi’yar 15, No. 30 (2012)) : 91-106. 
termasuk perkara baru, mengingat dalam fikih tidak terlalu populer pembahasan ini. Cerai gugat dengan alasan suami dipenjara dalam mazhab Maliki dan Hanbali pun tidak eksplisit disebut dalam kitab-kitab fikih mereka, dibolehkannya cerai gugat dengan alasan ini pada dasarnya dibangun atas alasan dibolehkannya cerai gugat karena suami hilang atau ghaib. ${ }^{9}$ Bahkan tidak jarang buku fikih munakahat kontemporer pun sebagian belum memasukkan pembahasan hal ini dalam bukunya. ${ }^{10}$

Penulis membatasi empat negara dengan pertimbangan masing masing negara mewakili salah satu mazhab empat. Selain itu, penulis memilih negara lain selain Indonesia yang mengundangkan UU hukum keluarganya di atas tahun 2000 yang relatif masih baru dan up to date. Mengingat banyak artikel maupun buku yang beredar masih banyak yang menggunakan UU lama yang sudah diamandemen atau bahkan dicabut.

Rumusan masalah dalam penelitian ini adalah : Pertama, bagaimana ketentuan fikih dan UU empat negara muslim mengenai kebolehan cerai gugat dengan alasan suami dipenjara? Kedua, apa persamaan dan perbedaan ketentuan fikih khususnya mazhab Maliki dan Hanbali dengan empat negara tersebut?

\section{Metode Penelitian}

Penelitian ini menggunakan pendekatan normatif atau doktrinal dengan metode perbandingan. Perbandingan ini dalam hukum Islam dikenal dengan perbandingan fikih dengan undang-undang atau dikenal di Timur Tengah dengan istilah muqaranah asy-syariah wa al-qanun. Sumber data mengunakan sumber data sekunder berupa literatur dan dokumentasi. Bahan hukum primer digali dari UU di masing-masing negara, sedang fikih menggunakan fikih empat mazhab sekaligus dalam pembahasannya. Bahan hukum sekunder dikumpulkan melalui buku maupun penjelasan dari ahli di bidang hukum keluarga. Analisis data dilakukan menggunakan konten analisis. ${ }^{11}$

\section{Pembahasan}

Dalam fikih, pada dasarnya hak talak ada di tangan suami. Namun, untuk mengakhiri pernikahan tidak hanya menjadi hak dan wewenang suami. Istri melalui bantuan

9 Muhammad Ali Syarthawi, Syarh Qanun al-Akhwal asy-Syakhshiyyah, ( Amman : Dar al-Fikr, 2010), hlm. 304.

10 Seperti buku fikih karya Badran Abu al-'Ain Badran ulama dunia dan Amir Syarifuddin ulama Indonesia ketika membahas perceraian karena putusan pengadilan, setelah menjabarkan alasan-alasan istri dapat menggugat cerai suami, ternyata penulis tidak membahas suami yang dipenjara. Lihat Badran Abu al-'Ain Badran, Ahkam az-Zawaj wa ath-Thalaq fi al-Islam, (t.tp : Dar at-Ta' lif, 1961), hlm. 285 dst. Amir Syarifuddin, Hukum Perkawinan Islam di Indonesia; Antara Fiqh Munakahat dan Undang-Undang Perkawinan, Cet. V, ( Jakarta : Kencana, 2015), hlm. 245-253. Karya Amr Abdul Mun'im Salim, al-Jami'fi Ahkam ath-Thalaq, ( t.np : Dar adh-Dhiya', t.t) yang khusus membahas masalah perceraian dalam fikih pun tidak membahas suami dipenjara sebagai alasan cerai gugat. Buku ini hanya menyinggung sekilas cerai gugat karena suami mafqud atau hilang.

11 Faisal Ananda Arfa \& Watni Marpaung, Metodologi Penelitian Hukum Islam, (Jakarta : Kencana, 2016), hlm. 56-59. 
pengadilan dapat berinisiatif mengakhiri pernikahan dengan alasan atau alasan-alasan tertentu yang dikemukakan para ulama. Ada alasan cerai gugat yang disepakati di kalangan ulama mazhab empat yakni cerai gugat karena aib atau cacat dengan sedikit variasi dalam penerapannya. Selanjutnya ada alasan-alasan lain yang masih diperselisihkan kebolehannya di kalangan mazhab empat, misalnya cerai gugat dengan alasan suami tidak mampu memberi nafkah, suami melakukan tindakan dharar, suami ghaib, suami hilang atau mafqud dan suami dipenjara.

\section{Perspektif Fikih Mazhab Empat}

Suami dipenjara sebagai alasan cerai gugat di kalangan empat mazhab disikapi menjadi dua pandangan besar. Kelompok pertama yang melarang suami dipenjara sebagai alasan untuk cerai gugat, dan kelompok kedua yang membolehkan suami dipenjara sebagai salah satu alasan cerai gugat. ${ }^{12}$ Pendapat yang melarang cerai dengan alasan suami dipenjara dikemukan ulama dari Mazhab Hanafi dan Syafi'i serta Zhahiri. Menurut kelompok ini, walau suami lama dipenjara tidak ada celah bagi istri untuk meminta cerai, sama saja apakah tempat penjaranya ia ketahui atau tidak. Kalau suami dipenjara, dianggap ghaib sementara yang ada kejelasan batas akhirnya. Jadi tidak pas kalau ketiadaan sementara disikapi dengan minta cerai. ${ }^{13}$ Untuk lebih rincinya, keterangan berikut akan menjelaskannya.

\section{Pandangan Mazhab Hanafi}

Dalam persoalan alasan cerai gugat, mazhab Hanafi bersikap ketat bahkan paling ketat di antara mazhab empat dengan cenderung menutup kebolehan cerai gugat karena alasan-alasan tertentu. Mazhab Hanafi membolehkan cerai gugat dengan alasan suami cacat. ${ }^{14}$ Cacat itu pun terbatas pada perkara yang menghalangi kemampuan hubungan seksual seperti impotensi dan terpotongnya dzakar (kemaluan pria). ${ }^{15}$ Sedang cerai gugat dengan alasan syiqaq, dharar, tidak diberi nafkah, suami ghaib, suami mafqud, ${ }^{16}$ dan suami dipenjara mazhab Hanafi tidak membenarkannya untuk dilakukan seorang istri. $^{17}$

12 Muhammad Ali Syarthawi, Syarh Qanun al-Akhwal asy-Syakhshiyyah, (Amman : Dar al-Fikr, 2010), hlm. 304.

13 Mahmud Abbas Shalih Abu Isa, "at-Tafriq Baina az-Zaujaini bi Sababi Habs az-Zauj fi al-Fiqh al-Islami wa al-Ma'mul bihi fi al-Mahakim asy-Syar'iyyah fi adh-Dhaffah al-Gharbiyyah”, Tesis, (Nablus : Universitas anNajah al-Wathaniyah, 2005), hlm. 39.

14 Ayat Syawisy Dalilah, “Inha` ar-Rabithah az-Zaujiyah bi Thalab az-Zaujah Dirasah Muqaranah baina al-Fiqh al-Islami wa Qanun al-Usrah al-Jaza iri wa Ba'dhu at-Tasyri’at al-Ahwal asy-Syakhshiyyah al-'Arabiyah”, Disertasi, (Tizi Wizu : Universitas Maulud Ma'mari, 2014), hlm. 139-140.

15 Amir Syarifuddin, Hukum Perkawinan Islam di Indonesia; Antara Fiqh Munakahat dan Undang-Undang Perkawinan, Cet. V, ( Jakarta : Kencana, 2015), hlm. 247.

16 Perbedaan suami ghaib dan mafqud adalah, dianggap ghaib kalau kepergian suami meninggalkan istri, alamat dan keberadaan suami diketahui,namun dalam tempo yang lama walau sudah diminta kembali ia tidak mau kembali. Sedang suami mafqud maksudnya suami itu dinyatakan hilang tanpa diketahui alamat dan keberadaannya, termasuk apakah ia masih hidup atau telah mati. Ayat Syawisy Dalilah, " Inha' ar-Rabithah az-Zaujiyah bi Thalab az-Zaujah Dirasah Muqaranah baina al-Fiqh al-Islami wa Qanun al-Usrah al-Jaza 'iri wa Ba'dhu at-Tasyri'at al-Ahwal asy-Syakhshiyyah al-'Arabiyah”, Disertasi, (Tizi Wizu : Universitas Maulud Ma'mari, 2014), hlm. 138, 155.

17 Al-Bamarni, Ahkam al-Usrah (az-Zawaj wa ath-Thalaq) baina al-Hanafiyyah wa asy-Syafi'iyyah Dirasah Muqaranah bi al-Qanun, (Aman : Dar al-Hamid li an-Nayar wa at-Tauzi', 2009), hlm. 291 dst. 


\section{Pandangan Mazhab Maliki}

Bertolak belakang dengan mazhab Hanafi yang mempersempit alasan cerai gugat, mazhab Maliki paling longgar dan mudah merestui istri menggugat cerai dengan alasan menolak mudarat dan menghilangkan kesulitan dalam kehidupan. Makanya alasan cerai gugat yang banyak dibahas dalam fikih, mazhab Maliki cenderung membenarkan dan mengakui. Cerai gugat dengan alasan syiqaq, dharar, tidak diberi nafkah, suami ghaib, serta karena suami mafqud. Namun, untuk alasan suami dipenjara, sebenarnya ulama mazhab Maliki (dan juga Hanbali) walau disebutsebut membolehkan cerai gugat karena suami dipenjara, tidak ditemukan pernyataan yang eksplit yang secara tegas membolehkan. Hal ini dilakukan dnegna jalan qiyas dengan kebolehan cerai gugat karena suami ghaib atau mafqud. ${ }^{18}$ Permohonan cerai ini boleh dilayangkan ke pengadilan setelah satu tahun dari mulai dipenjaranya suami. ${ }^{19}$

Al-Ajhuri salah seorang ulama Maliki berkata dalam Syarh al-Khalil sebagai berikut:

" Jika istri boleh menggugat cerai karena tidak diberi nafkah, maka demikian juga mestinya si istri lebih pantas dibolehkan menggugat cerai suaminya karena takut terjatuh zina karena bahaya tidak dikumpuli suami bisa mendorong terjadinya zina. Bukankah jika istri menggugurkan hak nafkahnya suami bisa mengambilnya, namun jika istri menggurkan hak seksualnya maka suami tidak bisa menepatinya dan istri harus mencabut pengguguran itu". ${ }^{20}$

Kutipan ini sebenarnya menyangkut cerai gugat dengan alasan suami tidak mampu memberi nafkah. Dengan alasan yang lebih berat, mestinya istri juga bisa menggugat cerai suami jika suaminya dipenjara dalam tempo tertentu, karena penderitaan istri lebih besar lagi yakni di samping istri tidak diberi nafkah juga tidak mendapat pemenuhan kebutuhan biologis dari suaminya.

Memang, mazhab Maliki dan Hanbali yang disebut-sebut membolehkan cerai gugat karena suami dipenjara tidak secara tegas atau eksplisit menyebutkannya dalam kitabkitab fikih mereka. ${ }^{21}$ Namun kebolehan ini didasarkan pada kebolehan cerai gugat karena alasan menghindari dharar, termasuk dharar yang perlu dihindari adalah dharar karena suami ghaib (pergi lama), mafqud (hilang) dan mahbus (dipenjara). Karena intinya sama, yakni istri bisa menderita jika suami terlibat dalam salah satu sebab di atas. ${ }^{22}$ Fikih mazhab

18 Ayat Syawisy Dalilah, "Iha` ar-Rabithah az-Zaujiyah bi Thalab az-Zaujah Dirasah Muqaranah baina al-Fiqh al-Islami wa Qanun al-Usrah al-Jaza 'iri wa Ba'dhu at-Tasyri'at al-Ahwal asy-Syakhshiyyah al-'Arabiyah”, Disertasi, (Tizi Wizu : Universitas Maulud Ma'mari, 2014), hlm. 172.

19 Wuzarah al-Auqaf wa asy-Su 'un al-Islamiyyah, Al-Mausu'ah al-Fiqhiyyah, Cet. II, ( Kuwait : Dar as-Salasil, 1404), Juz 29, hlm. 66. Periksa juga Sayyid Sabiq, Fiqh as-Sunnah, alih bahasa Asep Sobari dkk., (Jakarta : al-I'tisham, 2017), Jilid II., hlm. 473 dst.

20 Ahmad bin Ghanim bin Salim an-Nafrawi, Al-Fawakih ad-dawani 'ala Risalah Ibni Abi Zaidf al-Qarawaini, Maktabah ats-Tsaqafah ad-Diniyyah, juz III, hlm. 1026.

21 Syibli, Muhammad Musthafa, Ahkam al-Usrah fi al-Islam Dirasah Muqaranah baina Fiqh al-Madzahib asSunniyah wa al-Madzhab al-Ja'fari wa al-Qanun, (Beirut : Dar al-Jami'iyah, 1983), hlm. 613.

22 Hasani, “ at-Tafriq al-Qadha'i bi Sabab Habs az-Zauj fi at-Tasyri' al-Jazairi wa Ba'dhi at-Tasyri'at al“Arabiyyah”, Tesis, Jamia'ah Ziyan 'Asyur, Julfah, 2016, hlm. 18. 
Maliki sendiri membolehkan cerai gugat boleh difasakh walaupun kabar beritanya karena suami dipenjara setelah berlangsung sudah putus. Hal ini bisa difahami, jika suami satu tahun sejak suami dipenjara. ${ }^{23}$

Pertanyaannya, cerai gugat karena suami dipenjara kalau dikabulkan pengadilan termasuk perceraian apa? Dalam hal ini mazhab Maliki menghukumi dengan talak ba in, yakni talak di mana suami tidak bisa merujuk istri di masa iddahnya, namun masih bisa menikahinya lagi dengan akad nikah baru, tentunya kalau istrinya mau dinikahi lagi. ${ }^{24}$

\section{Pandangan Mazhab Syafi'i}

Dalam al-Mausu'ah al-Fiqhiyyah yang tertawan musuh dan kabar darinya sudah putus, istri tidak bisa difasakh pernikahannya oleh hakim, apalagi hanya sekedar dipenjara yang tempatnya diketahui dan beritanya belum putus. ${ }^{26}$

\section{Pandangan Mazhab Hanbali}

Mazhab Hanbali juga disebut-sebut membolehkan istri menggugat cerai karena alasan suami dipenjara, namun pernyataan resmi mazhab ini tidak terlalu jelas, hanya saja sebagian ulama mazhab Hanbali menjelaskan kebolehan itu dalam sebagian al-Kuwaitiyah, salah satu ensiklopedi fikih terlengkap sepengetahuan penulis, menyimpulkan dalam pembahasan cerai gugat karena suami ghaib, mafqud, dan mahbus (dipenjara) selalu mazhab Hanafi dan Syafi'i tidak membenarkan istri meminta cerai karena tiga alasan itu. ${ }^{25}$ Dinukil dari pendapat Imam Asy-Syafi'i pendiri mazhab Syafi'i, bahwa pernikahn suami yang tertawan, tidak fatwa mereka. ${ }^{27}$ Ibnu Taimiyah dari mazhab Hanbali yang paling jelas pendapatnya akan kebolehan cerai dengan alasan suami dipenjara, dan beliau berpendapat istri harus menunggu sampai empat tahun baru bisa dijadikan alasan bercerai. ${ }^{28}$ Sementara Imam Ahmad dalam kasus yang mirip dengan suami dipenjara, berfatwa bahwa suami yang pergi meninggalkan rumah tanpa alasan yang

23 Wuzarah al-Auqaf wa asy-Su 'un al-Islamiyyah, Al-Mausu'ah al-Fiqhiyyah, Cet. II, ( Kuwait : Dar as-Salasil, 1404), Juz 29, hlm. 66.

24 Sayyid Sabiq, Fiqh as-Sunnah, alih bahasa Asep Sobari dkk., Cet. VI, ( Jakarta : al-I’tishom, 2017), Jilid II, hlm. 479.

25 Wuzarah al-Auqaf wa asy-Syu un al-Islamiyyah, Al-Mausu'ah al-Fiqhiyyah al-Kuwaitiyyah, Mesir : Dar ashShafwah, 1404), juz 29, hlm 66-67. Periksa juga Abu Malik Kamal bin as-Sayyid Salim, Sahih Fiqh asSunnah, alih bahasa Khairil Amru Harahap dan Faisal Saleh, Sahih Fikih Sunnah, (Jakarta : Pustaka Azzam, 2016), Jilid II, hlm. 632 dst.

26 Ayat Syawisy Dalilah, "Inha` ar-Rabithah az-Zaujiyah bi Thalab az-Zaujah Dirasah Muqaranah baina al-Fiqh al-Islami wa Qanun al-Usrah al-Jaza'iri wa Ba'dhu at-Tasyri'at al-Ahwal asy-Syakhshiyyah al-'Arabiyah", Disertasi, (Tizi Wizu : Universitas Maulud Ma'mari, 2014), hlm. 139-140.

27 Mahmud Abbas Shalih Abu Isa, "at-Tafriq Baina az-Zaujaini bi Sababi Habs az-Zauj fi al-Fiqh al-Islami wa al-Ma'mul bihi fi al-Mahakim asy-Syar'iyyah fi adh-Dhaffah al-Gharbiyyah", Tesis, Universitas an-Najah alWathaniyah Nablus Palestina 2005, hlm. 40.

28 Adnan Ali an-Najjar, "at-Tafriq al-Qadha`i baina az-Zaujain Dirasah Fiqhiyyah Muqaranah baina bi Qanun al-Ahwal asy-Syakhshiyyah al-Falestin", Tesis, (Ghaza: Fakultas Syariah Universitas Islamiyyah, 2004), hlm. 126. 
dibenarkan lebih dari enam bulan, sedang istrinya tidak menerima maka ia dikirimi surat supaya pulang, jika ia menolak pulang, hakim dapat menceraikan keduanya, tentunya kalau ada gugatan dari istrinya sebagai tanda ketidakrelaannya.

Syarat-syarat yang dikemukan ulama yang membolehkan cerai gugat dengan alasan suami dipenjara dapat disimpulkan dari pendapat mazhab Maliki dan Hanbali sebagai berikut :

- Masa dipenjaranya suami cukup lama.

- Si istri takut akan fitnah (zina) yang dikawatirkan akan menimpanya.

- Perceraian itu harus dilakukan oleh hakim. ${ }^{29}$

- Kebolehan cerai gugat dengan alasan suami dipenjara dalam mazhab Maliki dan Hanbali dalam pengamatan al-Hasani berputar pada dua alasan yang dirasa akan membuat istri menderita, pertama karena istri terhalang mendapat nafkah jika suami dipenjara, kedua istri tidak terpenuhi kebutuhan seksualnya yang dikhawatirkan bisa tergoda dalam perbuatan keji (zina). ${ }^{30}$ Ibnu Taimiyah salah seorang ulama mazhab Hanbali menguatkan pendapat dibolehkannya istri menuntut cerai jika suaminya tidak mau atau mampu melakukan hubungan seksual dengannya, terbukti dalam kasus ila' dalam tempo empat bulan suami yang tidak mau mencampuri istrinya bisa diceraikan, maka dalam hal suami dipenjara sampai tahunan lebih layak untuk bisa diterapkan. ${ }^{31}$

Berapa lama seorang suami dipenjara sehingga istri boleh mengajukan cerai gugat? Dalam hal ini ulama mazhab ada beberapa pandangan. Menurut mazhab Maliki suami dipenjara setahun atau lebih. Sedang mazhab Hanbali menetapkan enam bulan atau lebih, sementara Ibnu Taimiyah salah seorang ulama mazhab Hanbali memfatwakan empat tahun atau lebih. ${ }^{32}$ Dari uraian singkat ini terlihat adanya perbedaan ijtihad ulama karena memang tidak ada nas yang secara eksplisit menyebut batas waktu, maka tidak heran kalau ada perbedaan ijtihad dari tempo enam bulan hingga empat puluh delapan bulan.

\section{Perbandingan Empat Negara Muslim}

\section{Indonesia}

Dalam pengamalan fikih, umat Islam di Indonesia mayoritas dipengaruhi mazhab Syafi'i. Mazhab Syafi'i kalau dicermati dalam kitab-kitab fikihnya -juga terutama mazhab Hanafi $^{33}$-cenderung mempersempit alasanalasan seorang istri bisa menggugat cerai.

29 http://saidagate.com/Saida/saidaBlogsDetails/8984, diakses 23 Agustus 2020.

30 Raziqi Murad Hasani, “ at-Tafriq al-Qadha i bi Sabab Habs az-Zauj fi at-Tasyri' al-Jazairi wa Ba'dhi atTasyri'at al-‘Arabiyyah”, Tesis, (Julfah: Jamia’ah Ziyan 'Asyur, 2016), hlm. 20.

31 Ibnu Taimiyah, al-Ikhtiyarat al-Fiqhiyyah, (Beirut : Dar al-Ma’rifah, 1978), hlm. 562.

32 Mahmud Abbas Shalih Abu Isa, at-Tafriq Baina az-Zaujaini bi Sababi Habs az-Zauj fi al-Fiqh al-Islami wa al-Ma'mul bihi fi al-Mahakim asy-Syar'iyyah fi adh-Dhaffah al-Gharbiyyah, Tesis, Universitas an-Najah alWathaniyah Nablus Palestina 2005, hlm. 47 - 49.

33 Mazhab Hanafi adalah mazhab yang paling sempit dalam urusan membolehkan cerai gugat istri dengan alasanalasan tertentu diikuti kemudia mazhab Syafi'i. Lihat Mahmud Abbas Shalih Abu Isa, "at-Tafriq Baina azZaujaini bi Sababi Habs az-Zauj fi al-Fiqh al-Islami wa al-Ma'mul bihi fi al-Mahakim asy-Syar'iyyah fi adhDhaffah al-Gharbiyyah", Tesis, (Nablus: Universitas an-Najah al-Wathaniyah, 2005), hlm. 13 dst. 
Hanya satu yang disepakati kalangan ulama mazhab empat yakni kebolehan gugat cerai dengan alasan terdapat aib atau cacat, di luar alasan itu mereka berbeda pendapat. ${ }^{34}$

Walau pengaruh mazhab Syafi'i cukup kuat di Indonesia, namun ternyata legislasi negara ini memberikan ruang bagi istri atau suami mengajukan cerai dengan alasan salah satu pihak dipenjara selama lima tahun atau lebih. Hal ini bisa diketahui dari Pasal 39 ayat 2 UU No. 1 tahun 1974 tentang Perkawinan Jo. Pasal 19 Peraturan Pemerintah No. 9 Tahun 1975 Tentang Pelaksanaan Undang-Undang Nomor 1 Tahun 1974 Tentang Perkawinan menetapkan sejumlah alasan untuk alasanalasan perceraian sebagai berikut: ${ }^{35}$

1. Salah satu pihak berbuat zina atau menjadi pemabok, pemadat, penjudi dan lain sebagainya yang sukar disembuhkan;

2. Salah satu pihak meninggalkan yang lain selama 2 (dua) tahun berturut-turut tanpa izin pihak yang lain dan tanpa alasan yang sah atau karena hal lain di luar kemampuannya;

3. Salah satu pihak mendapat hukuman penjara 5 (lima) tahun atau hukuman yang lebih berat setelah perkawinan berlangsung;
4. Salah satu pihak melakukan kekejaman atau penganiayaan berat yang membahayakan terhadap pihak yang lain;

5. Salah satu pihak mendapat cacat badan atau, penyakit yang mengakibatkan tidak dapat menjalankan kewajibannya sebagai suami/isteri;

6. Antara suami dan isteri terus menerus terjadi perselisihan dan pertengkaran dan tidak ada harapan akan hidup rukun lagi dalam rumah-tangga; ${ }^{36}$

Khusus yang beragama Islam, ada tambahan dua alasan perceraian selain alasanalasan di atas, sebagaimana diatur dalam Pasal 116 Kompilasi Hukum Islam yaitu: ${ }^{37}$

1. Suami melanggar taklik-talak;

2. Peralihan agama atau murtad yang menyebabkan terjadinya ketidakrukunan dalam rumah tangga. ${ }^{38}$

Suami dipenjara apalagi sampai lima tahun lebih sebagai alasan istri menggugat cerai cukup beralasan. Banyak kerugian dan penderitaan yang dialami istri ketika suaminya dipenjara seperti kesulitan dalam hal nafkah, kesusahan mengurusi rumah tangga sendirian, tidak terpenuhinya kebutuhan biologis, serta tekanan batin yang tidak ringan karena malu dan terhina. Suami sampai masuk penjara juga

34 Wuzarah al-Auqaf wa asy-Syu 'un al-Islamiyyah, Al-Mausu'ah al-Fiqhiyyah al-Kuwaitiyyah, (Mesir : Dar ashShafwah, 1404), juz 29, hlm. 67.

35 Muhammad Isa, "Perceraian di Luar Pengadilan Agama Menurut Perspektif Undang-Undang Nomor 1 Tahun 1974 dan Kompilasi Hukum Islam (Suatu Penelitian di Wilayah Hukum Mahkamah Syar'iyah Aceh Besar)", Jurnal Ilmu Hukum, Pascasarjana Universitas Syiah Kuala, Volume 2, No. 1, (Februari 2014) : 64.

36 Syaefuddin Haris, "Kedudukan Taklik Talak dalam Perkawinan Islam Ditinjau dari Hukum Perjanjian." Arena Hukum 6, no. 3 (2013): 336-359. Lihat juga Amir Syarifuddin, Hukum Perkawinan Islam di Indonesia; Antara Fiqh Munakahat dan Undang-Undang Perkawinan, ( Jakarta : Kencana, 2015), hlm. 228.

37 Isnawati Rais, "Tingginya Angka Cerai Gugat (Khulu') di Indonesia; Analisis Kritis Terhadap Penyebab dan Alternatif Solusi Mengatasinya", AL- 'ADALAH Vol. XII, No. 1, (Juni 2014) : 195.

38 Ahmad Rofiq, Hukum Perdata Islam di Indonesia, Cet. III, ( Jakarta : Rajawali Pers, 2017), hlm. 219. 
mengindikasikan suami berperilaku buruk dan sudah keterlaluan sehingga bisa mencoreng nama baik keluarga dan juga kerabat. ${ }^{39}$

Dengan demikian, hukum positif di Indonesia memberi ruang cerai gugat bagi istri jika suaminya dipenjara lima tahun atau hukuman yang lebih berat setelah perkawinan berlangsung. Dalam hal ini pendapat mazhab Syafi'i sudah ditinggalkan dan sebaliknya malah menggunakan mazhab Maliki dan Hanbali yang membolehkan. Namun, pembatasan masa hukuman suami lima tahun atau lebih menurut hemat penulis terlalu lama, mengingat mudarat yang dirasakan istri bisa jadi semakin berat dan menyulitkan hidupnya. Philipina sebagai negara tetangga Indonesia yang umat Islamnya juga menganut mazhab Syafi'i, menetapkan hukuman penjara satu tahun sebagai dasar istri sudah bisa menggugat cerai. $^{40}$

Satu hal lagi, pasal 119 KHI menetapkan cerai gugat yang berujung pada perceraian oleh pengadilan dihukumi talak ba in sughra. Talak ba in sughra menutup peluang suami merujuk istri walau dalam masa iddah, namun masih memberi peluang suami untuk menikah lagi dengan akad baru, tentunya juga dengan membayar mas kawin lagi dan memenuhi persyaratan lainnya. ${ }^{41}$

\section{Maroko}

Maroko disebut juga dengan nama al-Mamlakah al-Maghribiyah yang terletak di benua Afrika sebelah Barat. Merdeka dari penjajahan Perancis pada tanggal 2 Maret 1956. Maroko berbentuk kerajaan dengan jumlah penduduk sekitar 32 juta di tahun 2011. Bahasa utama yang dipakai adalah bahasa Arab dan Berber ditambah lagi penggunaan bahasa Perancis yang cukup luas di kalangan terpelajar. $^{42}$

Seperti negeri-negeri muslim di Afrika utara pada umumnya, rakyat Maroko pada umumnya menganut mazhab Maliki. Mazhab Maliki memiliki kekhasan selain banyak menggunakan amalan penduduk Madinah juga banyak bersandar pada maslahat mursalah. Dengan metode ini, mazhab Maliki dikenal luwes dalam persoalan muamalah dan lebih mudah menyelesaikan berbagai persolan hukum yang berkembang di masyarakat. Dengan metode ini pula tidak aneh kalau mazhab Maliki banyak mengakomodir kebutuhan istri dalam perceraian dengan memberi peluang cerai gugat dengan alasanalasan yang dapat merugikan istri. ${ }^{43}$

Mula-mula setelah merdeka, hukum keluarga di Maroko diatur melalui Mudawwanah al-Usrah yang diundangkan

39 Muhammad Syaifuddin dkk., Hukum Perceraian, (Jakarta : Sinar Grafika, 2014), hlm. 196.

40 Lihat Presidential Decree No.1083 a Decree to Ordain and Promulgate a Code Recognizing The System of Filipino Muslim Laws, Codifying Muslim Personal Laws, and Providing for Its Administration And for Other Purposes, Pasal 52 poin b. Diunduh melalui https://lawphil.net/statutes/presdecs/pd1977/pd_1083_1977.html, akses 29 Juli 2021.

41 Pasal 119 Kompilasi Hukum Islam, Inpres Nomor 1 Tahun 1991.

42 Ahmad Tholabi Kharlie dkk., Kodifikasi Hukum Keluarga Islam Kontemporer, (Jakarta : Kencana, 2020), hlm. 158-159.

43 Muhammad al-Mukhtar Wald Abah, Madkhal ila Ushul al-Fiqh al-Maliki, (Rabath : Dar Ibnu Hazm, 2011) 
pada tahun 1957-1958. ${ }^{44}$ Karena dirasa sudah

kurang bisa mengakomodasi perkembangan masyarakat Maroko, pada tahun 2004 diundangkanlah Mudawwanah al-Usrah yang baru. UU ini dipuji sedemikian rupa oleh beberapa ahli karena dianggap paling progresif di dunia Arab terutama menyangkut hak-hak wanita. ${ }^{45}$ Mudawwanah al-Usrah tetap disusun dengan pijakan utama mazhab Maliki, mazhab yang dominan di Maroko dan juga di Afrika Utara pada umumnya, ditambah praktek masyarakat setempat. ${ }^{46}$

Perceraian yang melibatkan pengadilan, dalam mudawwanah disebut dengan at-tathliq yang pembahasannya meliputi perceraian atas permintaan salah satu pihak karena terjadi syiqaq dan satu lagi perceraian karena sebabsebab lain. Sebab-sebab lain ini pada dasarnya alasan-alasan di mana seorang istri dapat menggugat cerai suaminya. Ada enam alasan, sebagaimana dapat dilihat pada pasal 98 Mudawwanah al-Usrah 2004, sebagai dasar istri menggugat cerai suami yakni; suami melanggar perjanjian nikah, suami melakukan dharar (tindakan yang membahayakan istri), suami tidak menafkahi istri, suami ghaib, suami cacat, suami melakukan ila' dan meninggalkan/mengabaikan istri. ${ }^{47}$
Ketentuan cerai gugat dalam legislasi Maroko bisa ditemukan dalam bab cerai karena suami ghaib. Suami ghaib maksudnya suami pergi meninggalkan istri dalam tempo yang cukup lama baik ada alasan kuat atau tidak. Suami dipenjara dimasukkan dalam bab yang sama karena ada kesamaan yakni samasama suami tidak ada di samping istri dalam tempo yang cukup lama. Hanya bedanya, suami dipenjara bukan atas dasar pilihannya alias dipaksa, sementara suami ghaib atas dasar pilihannya.

Maroko melalui Mudawawanah al-Usrah 2004 pasal 106 menetapkan suami dipenjara sebagai dasar istri bisa mengugat cerai.

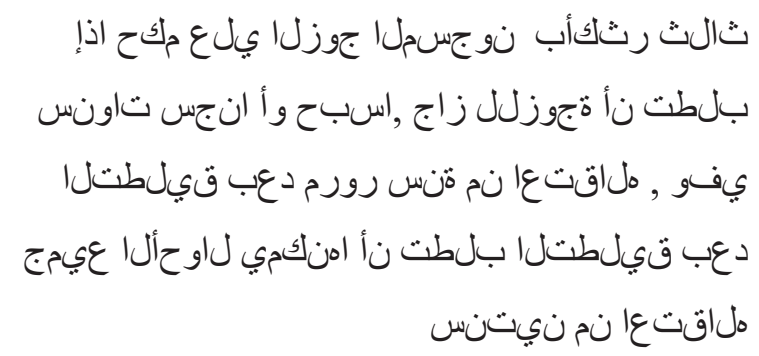

Pasal 106

Jika suami dihukum penjara atau kurungan lebih dari 3 tahun, istri dibolehkan mengajukan cerai gugat setelah berlalu masa satu tahun sejak penahanan suaminya, dalam segala kondisi istri boleh mengajukan cerai gugat setelah dua tahun sejak penahanan suami. $^{48}$

44 Tahir Mahmood, Personal Law in Islamic Countries, (New Delhi : Academi Of Law And Religion, 1987), hlm. 118.

45 Fatima Harrak, "The History And Significance of The New Moroccan Family Code." Institute for the Study of Islamic Thought in Africa (ISITA), Working Paper Series (2009).

46 Kristina Benson, "The Moroccan Personal Status Law and the Invention of Identity: A Case Study on the Relationship between Islam, Women, and the State." UCLA J. Islamic \& Near EL 12 (2013): 1.

47 Muhammad Faruji, Mudawwanah al-Usrah, (Dar al-Baidha': Matba'ah an-Najah al-Jadidah, 2012), hlm. 35. 48 Muhammad Faruji, Mudawwanah al-Usrah, (Dar al-Baidha`: Matba'ah an-Najah al-Jadidah, 2012), hlm. 37. 
Dari rumusan tersebut, dapat disarikan poin-poin penting; pertama suami dipenjara 3 tahun atau lebih, kedua sudah berlalu satu tahun sejak suami ditahan, kalau sudah berlalu dua tahun maka istri bebas mengajukan cerai gugat. Ketentuan ini selaras dengan ketentuan mazhab Maliki, mazhab yang dominan di Maroko, di mana istri dibolehkan mengajukan cerai gugat setelah berlalu satu tahun sejak penahanan suaminya untuk hukuman penjara yang telah final tiga tahun lebih. Jika putusan final belum keluar, maka setelah berlalu masa dua tahun istri baru bisa mengajukan cerai gugat. ${ }^{49}$ Ada pula yang memahami, walaupun suami hihukum penjara kurang dari 3 tahun, asal sudah melewati masa dua tahun sejak suami ditahan, maka istri bisa mengajukan cerai gugat ke pengadilan. ${ }^{50}$

Asas yang dijadikan alasan oleh ulama yang membolehkan mengajukan cerai karena suami dipenjara adalah menghilangkan dharar atas istri. Dharar dimaksud tidak kurang dari dua kemungkinan, yakni dharar karena tidak ternafkahinya istri selama suami dipenjara, dan dharar karena istri tidak mendapat nafkah batin dan dia khawatir bisa tergoda perselingkuhan dengan pria lain..$^{51}$
Sungguhpun mazhab Maliki pada dasarnya membolehkan cerai gugat dengan alasan suami dipenjara, namun tidak semua negara berlatar belakang mazhab Maliki mengadopsi dalam legislasinya. Tetangga dekat Maroko seperti Libya, Mauritania dan Tunisia dalam pengamatan penulis tidak mencantumkan secara eksplisit kebolehan ini. ${ }^{52}$

\section{Yordania}

Tidak kurang dari $92 \%$ penduduk Yordania memeluk agama Islam dengan dominasi mazhab Hanafi. Mazhab Hanafi cukup kokoh di negara ini mengingat Yordania pernah menjadi bagian dari Kerajaan Turki Usmani yang secara resmi menganut mazhab Hanafi sampai akhir Perang Dunia I sebelum dikuasai oleh Inggris. ${ }^{53}$

Yordania tercatat sudah mengamandemen beberapa kali UU hukum keluarganya. UU yang dikeluarkan tahun 1951 dimaksudkan untuk menggantikan UU Hukum Keluarga mengenai hak-hak keluarga yang dikeluarkan Turki Usmani tahun $1917 .{ }^{54}$ UU tahun 1951 ini kemudian dimandemen di tahun 1976, UU

49 Wuzarah Al-'Adl, Dalil 'Amali li Mudawwanah al-Usrah, ( Rabat: Jam'iyyah Al-Ma'lumah Al-Qanuniyyah wa al-Qadha'iyyah.Dalil amali li Mudawwanah al-Usrah, 2004), hlm. 78.

50 Ayat Syawisy Dalilah, "Inha` ar-Rabithah az-Zaujiyah bi Thalab az-Zaujah Dirasah Muqaranah baina al-Fiqh al-Islami wa Qanun al-Usrah al-Jaza iri wa Ba'dhu at-Tasyri'at al-Ahwal asy-Syakhshiyyah al-'Arabiyah", Disertasi, (Tizi Wizu : Universitas Maulud Ma’mari, 2014), hlm. 175.

51 Sayyid Sabiq, Fiqh as-Sunnah, alih bahasa Asep Sobari dkk., Cet. VI, ( Jakarta : al-I’tishom, 2017), Jilid II, hlm. 479.

52 Muhammad asy-Syafi'i, Qanun al-Usrah fi Duwal al-Maghrib al- 'Arabi, (Marakez : al-Mathba'ah al-Waraqah al-Wathaniyah, 2009) hlm. 191 dst.

53 Ahmad Tholabi Kharlie dkk., Kodifikasi Hukum Keluarga Islam Kontemporer, (Jakarta : Kencana, 2020), hlm. 116-117.

54 Tahir Mahmood, Personal Law in Islamic Countries, (New Delhi : Academi Of Law And Religion, 1987), hlm.73-74. 
tahun 1976 diamandemen lagi pada tahun 2010 dan terakhir kali dilakukan amandemen di tahun 2019.55

Dari empat negara yang penulis teliti, UU hukum keluarga Yordania merupakan yang terbaru karena ia baru dikeluarkan tahun 2019. Pada Fasal IV ditemukan bahasan perceraian berdasar putusan pengadilan (at-Tafriq al-Qadha $i$ ). Jenis-jenis cerai gugat di Yordania meliputi perceraian dengan tebusan atau at-tafriq li iftida ${ }^{56}{ }^{5}$ perceraian karena tidak dinafkahi atau at-tafriq $l i$ 'adam al-infaq, perceraian karena suami ghaib dan meninggalkan istri atau at-tafriq li al-ghiyab wa al-hajr, perceraian karena ila' dan Zhihar atau at-tafriq li al-Ila' wa az-Zhihar, perceraian karena dipenjara atau at-tafriq li al-habs, perceraian karena Syiqaq dan pertengkaran atau at-tafriq li sy-Syiqaq wa an-Niza', perceraian karena cacat atau at-tafriq li al'uyub, perceraian karena gagal membayar mahar atau at-tafriq li al- 'ajzi daf' al-mahr, perceraian karena enggan masuk Islam dan murtad atau at-tafriq li iba ‘ al-Islam wa ar-Riddah, perceraian karena hilang atau at-tafriq li al-faqd. Perceraian karena putusan pengadilan ini dalam UU tersebut diatur mulai pasal 114 sampai $144 .{ }^{57}$
Yordania melalui Qanun al-Ahwal asy-Syakhshiyyah al-Urduni Nomor 15 tahun 2019 mengatur cerai gugat karean suami di penjara pada bab Tafriq li al-Habs (Cerai karena penjara). Kebolehan cerai gugat karena suami dipenjara terdapat dalam satu pasal yakni pasal 125 yang berbunyi:

$$
\begin{aligned}
& \text { ميلع مولكحمل سوب مجلا ةجوزل : مدامل } \\
& \text { ثالث ةدم ةبير حلل ةديقم ةبوق مب بي عطق مكحب }
\end{aligned}
$$

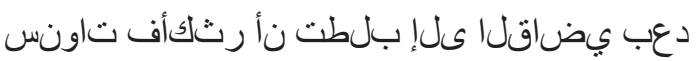

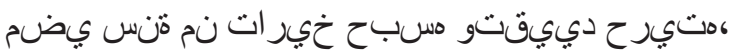

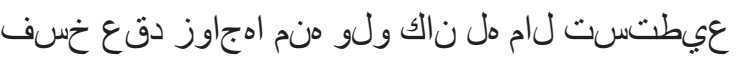

$$
\begin{aligned}
& \text { مكح رودص لبق منع جرفأ اذإف ،منم قافـن إلى }
\end{aligned}
$$

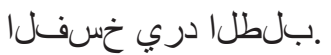

Pasal 125 :

Istri yang suaminya dipenjara yang dijatuhi putusan yang pasti (berkekuatan hukum tetap) dengan hukuman pembatasan kemerdekaannya selama 3 tahun atau lebih, boleh mengajukan cerai ke hakim setelah berlalu satu tahun dari tanggal sejak suami dipenjara dan dibatasi kebebasannya, maka pernikahanya akan difasakh walau suami memiliki harta yang sanggup menafkahi istri. Jika suami dibebaskan sebelum putusan fasakh keluar, maka permohonan istri untuk bercerai akan ditolak. ${ }^{58}$

55 Ahmad Tholabi Kharlie dkk., Kodifikasi Hukum Keluarga Islam Kontemporer, (Jakarta : Kencana, 2020), hlm. 117.

56 At-Tafriq li iftida ' maksudnya adalah istri menggugat cerai suami sebelum terjadi persetubuhan dengan jalan istri mengembalikan mahar dan hadiah yang sudah diberikan suaminya, juga nafkah suaminya selama menjadi suami istri, namun jika suami menolaknya, maka ia melibatkan pengadilan utnuk menceraikannya. Pengadilan tetap berusaha mendamaikan, namun jika gagal maka pernikahan itu difasakh oleh pengadilan. Lihat https:// www.ammonnews.net/article/289886, diakses 25 Juli 2021.

$57 \mathrm{UU}$ tersebut bisa diunduh melalui https://www.aliftaa.jo/ShowContent.aspx?Id=205\#.YObwOHBR3Sc, diunduh 22 Juli 2021.

58 https://www.aliftaa.jo/ShowContent.aspx?Id=205\#.XznEL6JR1PY, diakses 17 Agustus 2020. 
Memperhatikan rumusan pasal di atas, ada beberapa poin penting yang perlu digarisbawahi :

Pertama, hukuman penjara suami sudah berkekuatan hukum tetap. Kedua, masa hukuman minimal tiga tahun penjara. Ketiga, sudah berlalu masa suami dipenjara minimal satu tahun. Keempat, perkawinan akan difasakh walau suami memiliki cukup harta untuk menangung biaya istri. Kelima, fasakh perkawinan akan ditolak pengadilan jika suami sudah keluar dari penjara mendahului putusan fasakh.

Rumusan ini jelas tidak lagi mengikuti aturan dalam mazhab Hanafi, mazhab yang dominan di Yordania, namun lebih mendekati ketentuan dalam mazhab Maliki. Hanya saja pembuat UU di Yordania menambahkan dengan ketentuan fasakh perkawinan akan ditolak pengadilan jika suami sudah keluar dari penjara mendahului putusan fasakh. Ketentuan ini tidak ditemukan pada tiga negara yang lain yakni Indonesia, Maroko dan Qatar.

Perlu diketahui, perceraian yang dijatuhkan hakim karena suami dipenjara di Yordania dikategorikan sebagai talak ba in, bukan fasakh. Hal ini sesuai dengan pandangan mazhab Maliki dari pada mazhab Hanbali yang menganggap sebagai fasakh. ${ }^{59}$

\section{Qatar}

Qatar merupakan negara kecil berbentuk kerajaan yang sangat makmur di kawasan teluk. Qatar merdeka baru di tahun 1970 dengan jumlah penduduknya di tahun 2011 sekitar 1.600 .000 jiwa. Mayoritas penduduknya muslim bermazhab Hanbali. Walau sama dengan Yordania yang pernah menjadi bagian dari Kerajaan Turki Usmani sampai Perang Dunia I, namun pengaruh mazhab Hanafi tidak dominan di negara ini, sebaliknya pengaruh mazhab Hanbalilah yang kuat di negara ini. ${ }^{60}$

Sebelum tahun 2006, Qatar belum memiliki UU hukum keluarga yang komprehensif, baru di tahun 2006 pemerintah berhasil mengundangkan Qanun al-Usrah yang cukup lengkap. Di bagian awal dari UU ini dijelaskan bahwa UU ini disusun berdasar ketentuan fikih mazhab Hanbali dan akan diberlakukan bagi warga muslim yang tunduk pada mazhab Hanbali. Jika ada permasalahan hukum keluarga yang belum diatur dalam UU ini, hakim diberi kebebasan untuk menggali dari mazhab empat yang ada. ${ }^{61}$ Qanun Nomor 22 Tahun 2006 yang disahkan tanggal 29 Juni tahun 2006 ini memuat 304 pasal.

Qatar memberikan sejumlah alasan bagi istri utnuk menggugat cerai suami sebagaimana bisa dilihat pada Bab IV dengan

59 Muhammad Ali Syarthawi, Syarh Qanun al-Akhwal asy-Syakhshiyyah, Cet. III, (Amman : Dar al-Fikr, 2010), hlm. 304.

60 Ahmad Tholabi Kharlie dkk., Kodifikasi Hukum Keluarga Islam Kontemporer, (Jakarta : Kencana, 2020), hlm. 128-129.

61 Ahmad Tholabi Kharlie dkk., Kodifikasi Hukum Keluarga Islam Kontemporer, (Jakarta : Kencana, 2020), hlm. 130 . 
judul at-Tafriq bi Hukm al-Qadha' yang memuat sejumlah aturan berkaitan dengan kesempatan istri menggugat cerai suaminya. Fasal pertama memuat ketentuan cerai gugat karena suami cacat atau sakit (diatur mulai pasal 123-127). Fasal kedua memuat ketentuan cerai gugat karena suami gagal membayar mahar tunai (diatur pasal 128). Fasal ketiga memuat cerai gugat karena dharar dan syiqaq (diatur mulai pasal 129-136). Fasal keempat cerai gugat karena tidak memberi nafkah dan kemelaratan (diatur mulai pasal 137-142). Fasal kelima cerai gugat karena suami ghaib, hilang dan dipenjara (diatur mulai pasal 143 sampai 145). Fasal keenam cerai gugat karena ila', zhihar, li'an, riddah dan masuknya istri ke agama Islam sementara suaminya tetap non muslim (diatur mulai pasal 146 sampai 155). ${ }^{62}$

Selanjutnya, negara Qatar dengan memperhatikan ketentuan Qanun Nomor 22 Tahun 2006 pasal 145 memberikan peluang istri mengajukan cerai gugat dengan alasan suami dipenjara.

145 ةدامل

نع لقت ال قدمل يئامن مك حب جوزلاس سبح اذإ

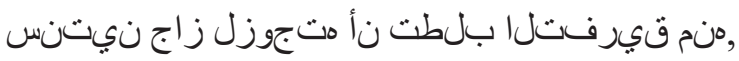
نم ةنس يضم دعب ال إقيرفت فـلاب مك حي الو

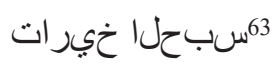

Pasal 145 :

Jika suami dihukum berdasar putusan final dalam tempo tidak kurang dari dua tahun, maka boleh bagi istri mengajukan cerai gugat dari suaminya. Tidak dijatuhkan putusan cerai kecuali setelah terlewati masa 1 tahun sejak tanggal suami dipenjara.

Dari rumusan pasal tersebut, dapat ditarik beberapa hal penting, pertama putusan hukum itu sudah final, kedua jangka hukuman tidak kurang dari dua tahun, dan ketiga bisa digugat cerai setelah masa penahanan suami melewati satu tahun. Dalam hal ini penulis belum menemukan keterangan, perceraian karena alasan ini termasuk talak ba in atau fasakh, mengingat hanya satu fasal saja dari UU ini yang mengaturnya.

Jika dibanding ketentuan fikih mazhab Hanbali, maka rumusan pasal tersebut ada yang sesuai ada yang tidak. Letak kesesuaian ada pada kebolehan cerai gugat dengan alasan suami dipenjara, sedang ketidaksesuainnya ada pada masa hukuman dan setelah berapa lama istri boleh mengajukan cerai gugat, di mana dalam mazhab Hanbali masa itu dibatasi enam bulan bukan dua atau satu tahun. Ketentuan dalam pasal tersebut malah lebih mirip dengan ketentuan fikih mazhab Maliki.

\section{Perbandingan Fikih dengan UU}

Cerai gugat dengan alasan suami dipenjara diperbolehkan oleh dua mazhab yakni mazhab Maliki dan Hanbali dengan analogi sama seperti kebolehan cerai gugat karena suami ghaib. Alasan utamanya memperbolehkan cerai gugat karena suami dipenjara dalam rangka menolak bahaya atau kerugian yang akan diderita istri. Sedang dua mazhab 
lainnya yakni mazhab Hanafi dan Syafi'i tidak memperbolehkan cerai gugat karena suami dipenjara.

Walau sama-sama memperbolehkan cerai gugat dengan alasan suami dipenjara, mazhab Maliki dan Hanbali juga berbeda dalam menentukan batas waktu kapan seorang istri dapat mengajukan cerai gugat. Mazhab Maliki memberi tempo setelah satu tahun, sementara mazhab Hanbali menetapkan batas waktu enam bulan sejak suami ditahan atau dipenjara. Perbedaan selanjutnya, cerai gugat karena suami dipenjara dianggap talak ba in dalam mazhab Maliki dan dianggap fasakh dalam mazhab Hanbali.

Sementara itu, perbedaan ketentuan antara mazhab Maliki dan Hanbali dengan UU Indonesia tampak pada lama waktu suami dipenjara. Hukum di Indonesia membatasi lima tahun lebih, sementara fikih Maliki satu tahun dan fikih Hanbali 6 bulan. Hukum di Indonesia menetapkan cerai gugat karena suami dipenjara sebagai talak ba in sughra sama dengan mazhab Maliki.

Sementara itu, perbedaan fikih mazhab Maliki dengan UU di Maroko tampak tipis saja. Ketika UU menyebut batas tiga tahun hukuman penjara, sebenarnya dalam mazhab Maliki juga ada qaul yang menyebutkan masa menunggu 3 tahun, walau yang lebih masyhur menyebut angka satu tahun. Ditambahkan dalam penjelasan UU, jika putusan hukuman final belum keluar, maka setelah lewat dua tahun sejak penahanan si istri sudah bisa melayangkan cerai gugat. Jika putusan hukuman sudah final maka cukup satu tahun sejak suami ditahan istri sudah bisa mengajukan cerai gugat. Cerai gugat juga bisa dilayangkan istri walau hukuman suami kurang dari 3 tahun asal sudah melewati masa dua tahun sejak penahanan.

Sedang perbandingan ketentuan fikih dengan legislasi di Yordania, UU Yordania menetapkan hukuman tiga tahun penjara yang telah berkekuatan hukum tetap sebagai syarat diperbolehkannya istri mengajukan cerai gugat. Hal ini berbeda dengan ketentuan fikih Maliki yang menetapkan masa satu tahun hukuman penjara sudah bisa mengajukan gugatan cerai. Sedang tempo mulai istri dapat mengugat cerai sama dengan ketentuan fikih mazhab Maliki yakni setelah berlalu masa 1 tahun. Di juga Yordania ada penegasan walau suami mampu menafkahi istri selama dipenjara tetap istri punya hak untuk meminta cerai gugat ke pengadilan. Jika suami dibebaskan sebelum putusan fasakh keluar, maka permohonan istri untuk bercerai akan ditolak, tambahan ini tidak ditemukan dalam fikih Maliki.

Selanjutnya, ketentuan UU di Qatar jika dibanding fikih mazhab Maliki dan Hanbali terletak pada lama hukuman penjara yang diterima suami, di mana Qatar menetapkan hukuman penjara dua tahun dan berkekuatan hukum tetap sudah cukup alasan buat melayangkan cerai gugat, sementara mazhab Maliki menetapkan satu tahun dan mazhab Hanbali enam bulan. Masa yang sudah harus dilewati suami menjalani hukuman penjara 
adalah satu tahun, baru setelah itu istri diberi hak untuk mengajukan fasakh nikah ke pengadilan. Ketentuan ini lebih mirip mazhab maliki dibanding mazhab Hanabli.

\section{Perbandingan UU Empat Negara}

Indonesia menetapkan waktu paling lama dalam hal istri dapat mengajukan cerai gugat lantaran suaminya dipenjara yakni lima tahun atau hukuman yang lebih berat. Maroko dan Yordania menetapkan hukuman penjara tiga tahun dan Qatar hanya dua tahun.
Dalam hal setelah berapa tahun istri boleh mengugat cerai, Indonesia menetapkan setelah 5 tahun berlalu, sedang Maroko, Yordania dan Qatar menetapkan satu tahun sejak suami ditahan.

Termasuk jenis talak apakah perceraian oleh pengadilan karena suami dipenjara? Indonesia menganggap sebagai talak ba in sughra, Maroko tidak ditemukan keterangan termasuk jenis talak atau fasakh, Yordania dianggap talak ba`in, Qatar juga tidak ditemukan penjelasan dalam UU.

Tabel 1. Perbandingan empat mazhab seputar kebolehan cerai gugat karena suami dipenjara

\begin{tabular}{|c|l|c|c|c|c|}
\hline No & \multicolumn{1}{|c|}{ Isu } & Hanafi & Maliki & Syafi'i & Hanbali \\
\hline 1. & $\begin{array}{l}\text { Memperbolehkan cerai gugat karena } \\
\text { suami dipenjara }\end{array}$ & - & $\sqrt{ }$ & - & $\sqrt{ }$ \\
\hline 2. & $\begin{array}{l}\text { Lama waktu sudah bisa mengajukan } \\
\text { cerai gugat }\end{array}$ & - & 1 tahun lebih & - & $\begin{array}{c}6 \text { bulan } \\
\text { lebih }\end{array}$ \\
\hline 3. & Jenis Talak & - & Ba in & - & Fasakh \\
\hline
\end{tabular}

Tabel 2. Perbandingan Hukuman Penjara Sebagai Alasan Gugat Cerai di Empat Negara Muslim

\begin{tabular}{|c|c|c|c|c|c|c|}
\hline No & Negara & $\begin{array}{c}\text { Putusan Final } \\
\text { Fasakh belum } \\
\text { Keluar, kalau } \\
\text { sudah keluar } \\
\text { gugatan cerai } \\
\text { ditolak }\end{array}$ & $\begin{array}{l}\text { Putusan } \\
\text { Final/tetap }\end{array}$ & $\begin{array}{c}\text { Lama } \\
\text { Penjara } \\
\text { suami }\end{array}$ & Jenis talak & $\begin{array}{c}\text { Masa suami } \\
\text { telah } \\
\text { menjalani } \\
\text { penjara }\end{array}$ \\
\hline & Indonesia & - & - & $\begin{array}{l}5 \text { tahun } \\
\text { lebih }\end{array}$ & $B a$ in sughra & - \\
\hline & Yordania & $\sqrt{ }$ & - & $\begin{array}{l}3 \text { tahun } \\
\text { lebih }\end{array}$ & Talak ba`in & 1 tahun lebih \\
\hline & Maroko & - & - & $\begin{array}{l}3 \text { tahun } \\
\text { lebih }\end{array}$ & - & 1 tahun lebih \\
\hline & Qatar & - & $\sqrt{ }$ & $\begin{array}{l}2 \text { tahun } \\
\text { lebih }\end{array}$ & - & 1 tahun lebih \\
\hline
\end{tabular}




\section{Simpulan}

Pernikahan sebagai perjanjian yang agung dan kokoh (mitsaqan Ghalizan) sudah semestinya dijaga dan dipertahankan esksistensinya dari ancaman perceraian. Namun fikih juga mengenal segala bentuk kumadaratan itu dihilangkan, dan menolak mudarat harus didahulukan dari menarik kemaslahatan. Sehingga mazhab yang banyak menggunakan maslahat sebagai acuan cenderung membenarkan cerai dengan alasan dharar dan turunannya.

Mazhab Hanafi dan Syafi'i yang tidak menjadikan maslahat sebagai salah satu sumber fikih tidak membuka peluang istri menuntut cerai dengan alasan suami dipenjara. Sedang Mazhab Maliki dan Hanbali yang dasar-dasar fikihnya menggunakan maslahat membuka kesempatan istri mengajukan cerai gugat dengan alasan suami dipenjara dalam tempo tertentu. Teori ini semakin kokoh dipakai dalam bangunan hukum keluarga sehingga tidak mengherankan jika negerinegeri muslim yang kuat dipengaruhi mazhab Hanafi dan Syafi'i tidak mengikuti fikih aliran mazhab tersebut dan berpaling ke mazhab Maliki dan Hanbali seperti ditunjukkan negara Indonesia dan Yordania.

Negara-negara yang membolehkan cerai gugat dengan alasan ini pun berbeda dalam menentukan lama suami dipenjara dan sejak kapan istri boleh melayangkan gugatan. Termasuk mereka juga berbeda dalam hal apakah jatuhnya talak karena suami dipenjara ini disebut talak ba in atau fasakh.

Indonesia, Maroko, Yordania, dan Qatar adalah di antara negara yang memberikan tempat untuk mengajukan cerai gugat dengan alasan suami dipenjara dengan sedikit ada variasi ketentuan. Dari sisi lamanya suami dipenjara terdapat rentang antara dua sampai lima tahun, sedang sejak kapan istri boleh mengajukan gugatan cerainya UU di empat negara menetapkan rentang dari enam bulan hingga satu tahun. Sebagian negara juga menetapkan putusan hukuman penjara tadi harus bersifat final dan berkekuatan hukum tetap seperti Yordania, namun sebagian lagi tidak secara tegas menetapkan syarat demikian.

Sebagai saran untuk perbaikan ketentuan hukum di Indonesia, kiranya perlu dipertimbangkan untuk mengurangi lama suami dipenjara dari 5 tahun menjadi 2 tahun agar derita istri yang ditinggal suami karena dipenjara tidak berkepanjangan, serta menghindari bahaya dan kerusakan lain yang mungkin timbul selama suami dipenjara. 


\section{DAFTAR PUSTAKA}

\section{Buku}

Al-Bamarni, Ismail Abu Bakr Ali. Ahkam al-Usrah (az-Zawaj wa ath-Thalaq) ba ina al-Hanafiyyah wa asy-Syafi'iyyah Dirasah Muqaranah bi al-Qanun. Aman : Dar al-Hamid li an-Nayar wa at-Tauzi', 2009.

Al-Faruji, Muhammad. Mudawwanah Al-Usrah. Dar Al-Baida': Matba'ah al-Najah al-Jadidah, 2012.

Arfa, Faisal Ananda \& Marpaung, Watni. Metodologi Penelitian Hukum Islam. Jakarta : Kencana, 2016.

Asy-Syafi'i, Muhammad. Az-Zawaj fi Mudawwanah al-Usrah. Marakesh : al-Mathba'ah al-Waraqah al-Wathaniyah, 2005.

Asy-Syafi'i, Muhammad. Qanun al-Usrah fi Duwal al-Maghrib al-'Arabi. Marakez : al-Mathba'ah al-Waraqah al-Wathaniyah, 2009.

az-Zuhaily, Wahbah. al-Fiqh al-Islami wa Adillatuhu. Damaskus : Dar al-Fikr, 1424. Juz 9.

Badran Abu al-'Ain Badran. Ahkam az-Zawaj wa ath-Thalaq fi al-Islam. t.tp : Dar at-Ta`lif, 1961.

Taimiyah, Ibnu. al-Ikhtiyarat al-Fiqhiyyah. Beirut : Dar al-Ma'rifah, 1978.

Kharlie, Ahmad Tholabi dkk. Kodifikasi Hukum Keluarga Islam Kontemporer. Jakarta : Kencana, 2020.
Mahmood, Tahir. Personal Law in Islamic Countries. New Delhi : Academi Of Law And Religion, 1987.

Rofiq, Ahmad. Hukum Perdata Islam di Indonesia. Jakarta : Rajawali Pers, 2017.

Sabiq, Sayyid. Fiqh as-Sunnah. alih bahasa Asep Sobari dkk., Jakarta : al-I'tishom, 2017. Jilid II.

Salim, Amr Abdul Mun'im. al-Jami'fi Ahkam ath-Thalaq. t.np : Dar adh-Dhiya', t.t.

Syaifuddin, Muhammad dkk. Hukum Perceraian. Jakarta : Sinar Grafika, 2014.

Syarifuddin, Amir. Hukum Perkawinan Islam di Indonesia; Antara Figh Munakahat dan Undang-Undang Perkawinan. Jakarta : Kencana, 2015.

Syarthawi, Muhammad Ali. Syarh Qanun al-Akhwal asy-Syakhshiyyah. Amman : Dar al-Fikr, 2010.

Syibli, Muhammad Musthafa.Ahkamal-Usrah fi al-Islam Dirasah Muqaranah ba ina Figh al-Madzahib as-Sunniyah wa al-Madzhab al-Ja'fari wa al-Qanun. Beirut : Dar al-Jami'iiyah, 1983.

WuzarahAl-'Adl.Dalil 'Amali liMudawwanah al-Usrah. Rabat : Jam'iyyah Al-Ma'lumah Al-Qanuniyyah wa al-Qadha'iyyah, 2004.

Wuzarahal-Auqafwaasy-Su unal-Islamiyyah. Al-Mausu'ah al-Fiqhiyyah. Kuwait : Dar as-Salasil, 1404. Juz 29. 
Salim, Abu Malik Kamal bin as-Sayyid. Sahih

Fiqh as-Sunnah. alih bahasa Khairil Amru Harahap dan Faisal Saleh. Sahih Fikih Sunnah. Jakarta : Pustaka Azzam, 2016. Jilids II.

\section{Jurnal}

Benson, Kristina. "The Moroccan Personal Status Law and the Invention of Identity: A Case Study on the Relationship between Islam, Women, and the State." UCLA J. Islamic \& Near EL 12 (2013): 1.

Fitra Mulyawan, "Pelaksanaan Penyelesaian Perkara Cerai Gugat dengan Alasan Suami di Penjara", Ranah Research : Journal of Multidicsiplinary Research and Development, Volume 1, Issue 4, (Agustus 2019).

Haris, Syaefuddin. "Kedudukan Taklik Talak dalam Perkawinan Islam Ditinjau dari Hukum Perjanjian.” Arena Hukum 6, no. 3 (2013): 336-359.

Linawati, Iis, Septiandani, Dian, Yulistyowati, Efi. " Fasakh Perkawinan Karena Istri Mengalami Gangguan Jiwa: Studi Kasus Putusan Pengadilan Agama Pati No. 1899/Pdt.G/2013/PA.Pt.”, HUMANI (Hukum dan Masyarakat Madani), Volume 7 No. 3 (Desember 2017) : 5 .

Rais, Isnawati. “ Tingginya Angka Cerai Gugat (Khulu') di Indonesia; Analisis Kritis Terhadap Penyebab dan Alternatif
Solusi Mengatasinya, $A L-' A D A L A H$, Vol. XII, No. 1 (Juni 2014) : 15.

Mahmud, Mek Wok, and Siti Zulaikha binti Mokhtar. "Mafqūd and Fasakh in the Writings of Muslim Jurists and Provisions of Malaysian Federal Territory Islamic Family Law: The Case of MH 370 Missing Plane.” Intellectual Discourse 25, no. Special Is (2017): 575-588.

Sulthonudin, Jefri, and Musthofa, Abdul Halim. "Cerai Gugat Istri Akibat Suami Dipidana Penjara Menurut Perspektif Hukum Islam dan Hukum Positif." Legitima: Jurnal Hukum Keluarga Islam 2, no. 1 (2019): 1-16.

Nashr, Salman, " at-Tafriq al-Qadha 'i ba in az-Zaujaian bi Sabab al-Fuqdan, wa al-Ghiyab wa al-Habs Dirasah fi al-Fiqh al-Islami wa Qanun al-Usrah al-Jazairi”, al-Mi'yar 15, No. 30 (2012)) : 91-106.

asy-Syamri, Haidar Husain Kadzim dkk., "Haqq az-Zaujah fi Thalab at-Tafriq min Zaujiha al-Mahbus Dirasah Muqaranah bi al-Fiqh al-Islami”, Journal Of Kufa Legal And Political Science 1, No. 42/2, (2019).

Harrak, Fatima. "The History and Significance of The New Moroccan Family Code." Institute for the Study of Islamic Thought in Africa (ISITA), Working Paper Series (2009). 


\section{Tesis \& Disertasi}

an-Najjar, Adnan Ali. "at-Tafriq al-Qadha`i ba ina az-Zaujain Dirasah Fiqhiyyah Muqaranah ba ina bi Qanun al-Ahwal asy-Syakhshiyyah al-Falestin". Tesis. Ghaza : Universitas Islamiyyah, 2004. Tidak dipublikasikan.

Hasani, Raziqi Murad, “ at-Tafriq al-Qadha`i bi Sabab Habs az-Zauj fi at-Tasyri' al-Jazairi wa Ba'dhi at-Tasyri'at al-'Arabiyyah". Tesis. Julfah : Jamia'ah Ziyan 'Asyur, 2016. Tidak dipublikasikan.

Abu Isa, Mahmud Abbas Shalih. "at-Tafriq Ba ina az-Zaujaini bi Sababi Habs az-Zauj fi al-Fiqh al-Islami wa al-Ma'mul bihi fi al-Mahakim asy-Syar'iyyah fi adh-Dhaffah al-Gharbiyyah". Tesis, Nablus :Universitas an-Najah al-Wathaniyah, 2005. Tidak dipublikasikan.

Dalilah, Ayat Syawisy. " Inha' ar-Rabithah az-Zaujiyah bi Thalab az-Zaujah Dirasah Muqaranah baina al-Fiqh al-Islami wa Qanun al-Usrah al-Jaza`iri wa Ba'dhu at-Tasyri'at al-Ahwal asy-Syakhshiyyah al-'Arabiyah". Disertasi, Tizi Wizu : Universitas Maulud Ma'mari, 2014. Tidak dipublikasikan.

\section{Perundang-undangan}

UU Nomor 1 Tahun 1974 tentang Perkawinan.

Peraturan Pemerintah Republik Indonesia Nomor 9 Tahun 1975 Tentang
Pelaksanaan Undang-Undang Nomor 1

Tahun 1974 Tentang Perkawinan.

Instruksi Presiden Nomor 1 Tahun 1991 tentang Penyebarluasan Kompilasi Hukum Islam.

Qanun al-Usrah Nomor 22 Tahun 2006, Qatar.

Mudawawanah al-Usrah 2004, Maroko.

Qanun al-Ahwal asy-Syakhshiyyah al-Urduni Nomor 15 tahun 2019, Yordania.

\section{Naskah Internet}

http://arabic.dci-palestine.org/sites/arabic. dci-palestine.org/files/qanwn_ al-ahwal_al-shkhsyh_1snh_1976.pdf, diunduh 23 Agustus 2020.

http://hrlibrary.umn.edu/arabic/Yemeni_ Laws/Yemeni_Laws147.pdf, diunduh 25 Agustus 2020.

http://iraqld.hjc.iq:8080/LoadArticle. aspx?SC $=051120078254217$, diunduh 27 Agustus 2020.

h t t p : / / s a id a gat e . c o m / S a id a / saidaBlogsDetails/8984, diakses 23 Agustus 2020.

http://www.ilo.org/dyn/travail/docs/652/ Explanatory\%20Memorandum.pdf, diakses 23 Agustus 2020.

https://www.aliftaa.jo/ShowContent. aspx?Id=205\#.XznEL6JR1PY, diakses 17 Agustus 2020.

https://www.aliftaa.jo/Show Content. aspx? $I d=205$, diunduh penulis 25 Agustus 2020.

https://www.dc.gov.ae/PublicServices/ 
LegislationDetails.aspx?LawKey=681, https://www.aliftaa.jo/ShowContent. diakses 24 Agustus 2020. aspx? Id=205\#. YObwOHBR3 Sc, https://www.legalaffairs.gov.bh/13481. diunduh 22 Juli 2021. aspx?cms=, diakses 17 Agustus 2020.

https://www.ammonnews.net/article/289886, Muhammad bin Abdullah al-Hasyimi, diakses 25 Juli 2021. “ Zawiyah Qanuniyah: al-Ahwal https://www.almeezan.qa/LawView. asy-Syakhshiyyah (146) Tathliq aspx?opt\&LawID $=2558 \&$ language $=$ ar, az-Zaujah al-Mahbus Zaujuha”, dalam diakses 27 Juli 2021. http://alwatan.com/details/321761, https://lawphil.net/statutes/presdecs/pd1977/ diakses 17 Agustus 2020. pd_1083_1977.html, akses 29 Juli 2021. 